\title{
Performance of Pearl Millet Hybrids for Earliness and Grain Yield in Indian Hot Arid Region
}

\author{
R.K. Solanki ${ }^{1}{ }^{*}$, R.K. Kakani ${ }^{1}$, A.K. Jukanti ${ }^{2}$, S.K. Singh ${ }^{1}$ and R.K. Bhatt ${ }^{1}$ \\ ${ }^{I}$ Division of Plant Improvement and Pest Management, ICAR-CAZRI, \\ Jodhpur-342003, Rajasthan (India) \\ ${ }^{2}$ ICAR-IIRR, Hyderabad, Telangana (India) \\ *Corresponding author
}

\section{A B S T R A C T}

\begin{tabular}{|l|}
\hline Ke y w o r d s \\
Arid region, Pearl \\
millet, Hybrid, \\
$\begin{array}{l}\text { Earliness, Grain } \\
\text { yield }\end{array}$ \\
\hline Article Info \\
\hline $\begin{array}{l}\text { Accepted: } \\
\text { 15 January } 2019 \\
\text { Available Online: } \\
\text { 10 February } 2019\end{array}$ \\
\hline
\end{tabular}

Pearl millet is important crop of arid parts, mainly grown for fodder and grain. The present productivity level of the arid region is low and needs to be increased. Hybrids have higher potential as compared to OPVs in pearl millet, hence development of large number of hybrids and subsequently its assessment in arid environment is very much essential. 184 single cross hybrids were assessed in arid region of Rajasthan during Kharif 2017 for earliness, grain yield and other traits. Average grain yield of test hybrids was $27.63 \mathrm{q} / \mathrm{ha}$ with minimum of $10.2 \mathrm{q} /$ ha and maximum of $42.5 \mathrm{q} / \mathrm{ha}$. Only 45 test hybrids had days to $50 \%$ flowering less than 45 days, among them hybrids viz., ICMA 93333 x CZI 2003/1, ICMA 97111 x CZI 2003/1, ICMA 04999 x CZI 2010/11, ICMA 05444 x CZI 2003/1 and ICMA 93333 x CZI $2007 / 9$ yielded more than $30 \mathrm{q} / \mathrm{ha}$. Correlation was found to be positive and significant for grain yield with fodder yield and fodder yield with days to flowering, suggesting earliness may reduce fodder yield significantly. Hence it is necessary to breed highly vigorous early hybrids for grain and fodder both for the arid region.

\section{Introduction}

Agro-ecological resources in association with adaptive crops decide the agriculture potential of a cropping system, arid or dry land ecology are resilient environments with limited option of crop cultivation mainly due to low rainfall, very high temperature and low fertile soils. Crop productivity is essential for profitable agriculture, high yielding varieties and improved cultivation practices have provided better production environments. Coarse cereal or millet crops are integral part of dryland agriculture due to inherent potential to adopt well under drought and high temperature conditions.

Pearl millet (Pennisetum glaucum L.) is important multi-purpose coarse grain (1) of high nutritive value $(2,3)$ and the significance of millets in sustainable agriculture is well recognized, in year 2017 Government of Indian has declared millet crops as 'NutriCereals' by gazette notification [G.No: 44/2017-NFSM (E)]. Pearl millet holds the highest acreage among millets and is pre- 
dominantly grown in the western arid/semi arid regions for grain and fodder. In India it is cultivated in around 8.0 million hectare (mha) area contributing 9.63 million tonnes $(\mathrm{mt})$ of grain. In western region, Rajasthan state covers 56 per cent of national acreage of which 73 per cent area lies in hot arid parts of the state, contributing 4.01 and 2.32 million tonnes of grains respectively (4). Interestingly, pearl millet productivity has increased noticeably over time, in 1981 it was $458 \mathrm{~kg} \mathrm{ha}^{-1}$ which reached $1147 \mathrm{~kg} \mathrm{ha}^{-1}$ in 2017 (4, 5). Improved cultivars in pearl millet basically OPVs (Open pollinated varieties) and $\mathrm{SCH}$ (Single cross hybrids) are cultivated in large, but hybrids yield higher than OPVs with yield advantage ranging from 19 to 35 percent (5). In Rajasthan pearl millet is cultivated in hot arid parts i.e., in Jodhpur, Bikaner, Sikar, Jalore and Ganga Nagar regions; Bikaner and Jodhpur have lowest productivity accounting 5.77 and $6.30 \mathrm{q} \mathrm{ha}^{-1}$, but in acreage Jodhpur ranks first with 1.343 mha followed by Sikar (0.979 mha) and Bikaner (0.598 mha) (4).

Varieties have contributed significantly in increasing the pearl millet grain production, therefore to enhance the low productivity of hot arid regions its necessary to develop early high yielding hybrids having tolerance to drought, high temperature and diseases mainly downy mildew and blast. Genetic performance of hybrids in arid environment has been assessed in past, many hybrid cultivars have been developed which are getting popularity for commercial cultivation $(4,6)$. Breeding is a continuous process and it's necessary to develop large number of high yielding hybrids for harsh arid environment. Screening of hybrids under target environment can definitely provide opportunities to identify and develop better cultivars for arid farmers. In the present investigation 184 single cross hybrids were evaluated for grain yield and other traits in arid region of Rajasthan, identified promising early hybrids with high fertility restoration can be further evaluated at multi-locations in arid region.

\section{Materials and Methods}

Single cross test hybrids (184) were developed at ICRISAT, Patancheru during Summer-2017 using twelve male sterile (ms) lines of ICRISAT, Patancheru viz., ICMA (ICRISAT Millet A) lines of designated number 00777, 04999, 08111, 09111, 09666, 841, 88004, 92777, 93333, 97111, 05777 and CAZRI ms line CZMA 21 were randomly crossed with 27 inbred restorers developed by CAZRI viz., CZI (CAZRI Inbred) lines of designated number 99/8, 2000/13, 2000/7, 2002/15, 2002/19, 2003/1, 2003/8, 2005/22, 2007/11，2007/7，2007/9, 2008/4, 2008/8, 2010/11, 2010/14, 2010/5, 2011/2, 2011/7, 2012/10, 2012/8, 2013/11, 2013/8, 2014/1, 2014/3, 2014/5, 2014/6, 2014/7. These hybrids were evaluated for grain yield and other agro-morphological traits at ICARCAZRI, Jodhpur research farm $\left(26^{\circ} 18^{\prime} \mathrm{N}\right.$ and $73^{\circ} 01^{\prime} \mathrm{E}$ ) in four trials located in the same field laid continuously i.e., Hybrid Trial I (HT-I), HT-II, HT-III and HT-IV, each HT comprised of 46 test hybrids and four check varieties. Hybrid trials were conducted in RBD with three replication, each entry was planted in 2 rows of $4 \mathrm{~m}$ length with $60 \mathrm{~cm}$ row spacing and $12-15 \mathrm{~cm}$ plant to plant distance was maintained by thinning at $12-15$ days stage of crop growth. Trials were sown immediately after rainfall in month of June 2017; at the time of sowing fertilizer N @ of $20 \mathrm{~kg} / \mathrm{ha}$ and $\mathrm{P}_{2} \mathrm{O}_{5} @ 20 \mathrm{~kg} / \mathrm{ha}$ was applied, followed by $20 \mathrm{~kg} \mathrm{~N} / \mathrm{ha}$ as top dressing and maintained as rainfed throughout the season. During the season, $361 \mathrm{~mm}$ rainfall was received with 10 well distributed events of more than $10 \mathrm{~mm}$ rainfall; overall the crop performance was good as no water stress was observed. Observation were recorded for days 
to $50 \%$ flowering (DF50), plant height $(\mathrm{cm})$ (PH), number of effective tillers (ET), ear head length $(\mathrm{cm})($ EHL), ear head girth $(\mathrm{cm})$ (EHG), test weight (g) (TW), fodder yield $(\mathrm{q} / \mathrm{ha})(\mathrm{FY})$, grain yield $(\mathrm{q} / \mathrm{ha})(\mathrm{GY})$. All the trials were analysed separately using Indostat software; Independent comparison of hybrids was done on mean values in each HT and later pooled analysis of mean was also done to have an overall view. Grain yield correlation with other agro-morphological traits was also worked out to get a view of association involved in phenotypic expression.

\section{Results and Discussion}

Analysis of variance indicated significant differences among 184 test cross hybrids in the four hybrid trials (Table 1). The mean performance of test hybrids showed huge variation for the traits studied (Table 2), among 184 hybrids 77 showed high fertility restoration, 28 had partial fertility restoration and 79 combinations failed restore fertility. The average grain yield of 184 test hybrids was calculated irrespective of fertility restoration to see the potential of hybrid in arid regions, the overall mean was $27 \mathrm{q} \mathrm{ha}^{-1}$ with minimum of $10.2 \mathrm{q} \mathrm{ha}^{-1}$ and maximum of $\mathrm{q} \mathrm{ha}^{-1}$ (Table 3), which is higher than the Rajasthan state mean $\left(8.70 \mathrm{q} \mathrm{ha}^{-1}\right)$ and Jodhpur Region mean (6.30 q ha ${ }^{-1}$ ) (4). Higher grain yield of test hybrids is coupled effect of hybrid vigour and good rainfall, hence it clearly suggests that hybrids have good potential under favorable environment in arid regions.

Variation based on overall mean showed that days to $50 \%$ flowering had minimum variation $(5.49 \%)$ as expected in test hybrids due to product of early restorer inbreds; variation was also low for plant height (8.6 $\%)$, ear head girth (9.4\%). High variation was observed for tillers per plant (24.91 \%), fodder yield (24.26\%; maximum yield of $112.5 \mathrm{q} \mathrm{ha}^{-1}$ and minimum of $26.7 \mathrm{q} \mathrm{ha}^{-1}$, followed by grain yield (20.68\%). Further hybrids were analyzed independently in each trial as per experimental design to minimize the effect of field heterogeneity over larger area on hybrid performance.

In arid regions early high yielding hybrids are very much essential to be developed, hence, based on earliness (DF50 \% < 45 days), grain yield (> $20 \mathrm{q} \mathrm{ha}^{-1}$ ) and high fertility restoration percentage 14 promising test hybrids were identified (Table 2); of which ICMA 93333 x CZI 2003/1, ICMA 97111 x CZI 2003/1, ICMA 04999 x CZI 2010/11, ICMA 05444 x CZI 2003/1 and ICMA 93333 $x$ CZI 2007/9 yielded more than $30 \mathrm{q} \mathrm{ha}^{-1}$. These hybrids also showed resistant reaction against downy mildew in sick conditions.

Correlation of grain yield was maximum and positive with fodder yield (0.60) followed by plant height (0.20), ear head length (0.15) and ear head girth (0.15). Fodder yield was significantly correlated in positive direction with plant height $(0.46)$ and days to flowering (0.41) (Table 4). The objective of breeding dual purpose hybrids for fodder and grain is addressed in the set of hybrids developed. On the other hand incorporating earliness in hybrids will cause yield loss for fodder which will subsequently reduce the grain yield, hence for breeding early hybrids it's necessary to have very high vigour in hybrids for biological growth and high grain yield.

High grain yield and earliness in hybrids is the prime requirement for developing cultivars suitable for hot arid regions as they can escape terminal drought due to problem of scantly and erratic rainfall patterns. Dual purpose objective of getting more fodder and grain is important as fodder requirement is met significantly by pearl millet harvest in arid parts. 
Table.1 ANOVA for days to 50\% flowering, fodder yield (q/ha), grain yield (q/ha), test weight (g)

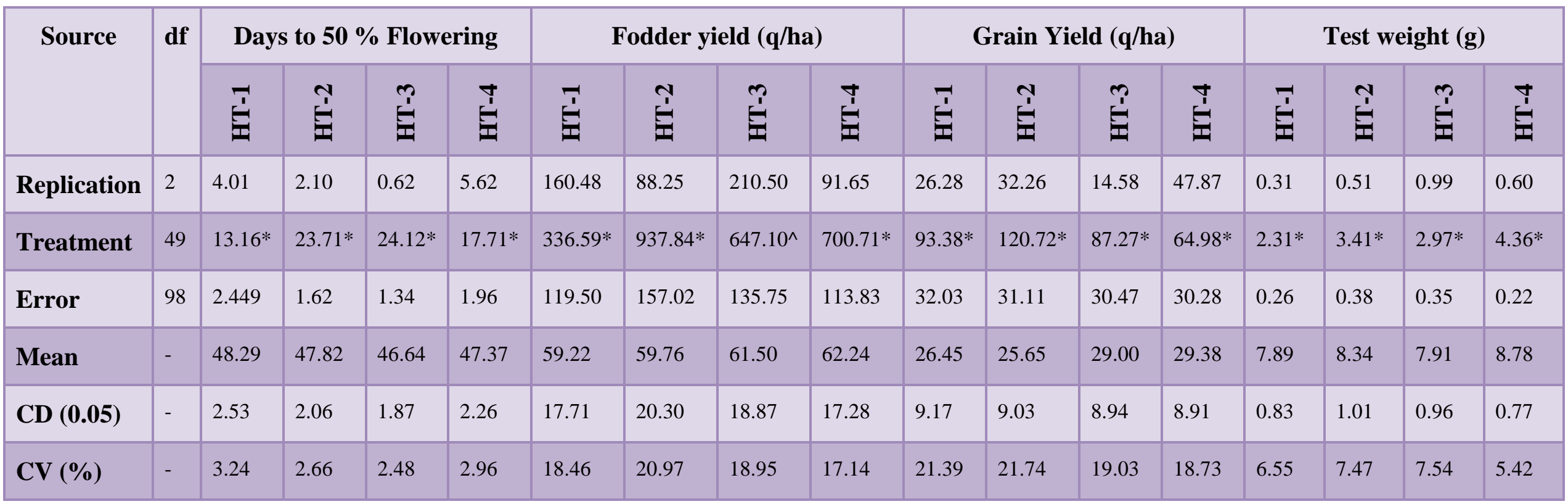


Table.2 Superior test hybrids having high fertility restoration, earliness and high grain yield

\begin{tabular}{|c|c|c|c|c|c|c|c|c|c|c|}
\hline Trial & Single cross test hybrids & $\begin{array}{c}\text { Days to } \\
50 \% \\
\text { Flowering }\end{array}$ & $\begin{array}{c}\text { Plant } \\
\text { Height } \\
\text { (cm) }\end{array}$ & $\begin{array}{c}\text { Ear } \\
\text { head } \\
\text { length } \\
(\mathrm{cm})\end{array}$ & $\begin{array}{l}\text { Ear } \\
\text { head } \\
\text { girth } \\
(\mathrm{cm})\end{array}$ & $\begin{array}{l}\text { No of } \\
\text { effective } \\
\text { tillers }\end{array}$ & $\begin{array}{c}\text { Test } \\
\text { weight } \\
\text { (g) }\end{array}$ & $\begin{array}{c}\text { Fodder } \\
\text { yield } \\
\left(\mathbf{q} \text { ha }^{-1}\right)\end{array}$ & $\begin{array}{l}\text { Grain } \\
\text { yield } \\
\left(\mathbf{q} \text { ha }^{-1}\right)\end{array}$ & $\begin{array}{c}\text { Rank as } \\
\text { per grain } \\
\text { yield }\end{array}$ \\
\hline \multirow[t]{4}{*}{ HT-1 } & ICMA 04999 x CZI 2010/11 & 45 & 217.3 & 19.8 & 2.5 & 3.0 & 7.7 & 72.6 & 32.8 & 3 \\
\hline & ICMA 93333 x 2007/9 & 44 & 206.9 & 20.3 & 2.8 & 2.7 & 7.4 & 65.6 & 31.6 & 5 \\
\hline & CZMS 21A x CZI 2014/3 & 45 & 212.8 & 23.6 & 2.3 & 2.0 & 6.8 & 46.2 & 28.6 & 7 \\
\hline & ICMA 05444 x CZI 2010/11 & 45 & 216.7 & 19.7 & 2.4 & 2.9 & 8.5 & 70.8 & 27.0 & 9 \\
\hline \multirow[t]{5}{*}{ HT-2 } & ICMA 93333 x CZI 2003/1 & 44 & 211.1 & 18.6 & 2.3 & 2.1 & 7.3 & 86.1 & 35.0 & 1 \\
\hline & ICMA 97111 x CZI 2003/1 & 45 & 215.8 & 21.4 & 2.6 & 1.8 & 9.0 & 61.1 & 33.2 & 2 \\
\hline & ICMA 97111 x CZI 2014/5 & 45 & 237.4 & 22.4 & 2.4 & 2.4 & 8.6 & 54.5 & 27.1 & 8 \\
\hline & ICMA 841 x CZI 2000/7 & 45 & 222.7 & 25.4 & 2.1 & 3.2 & 9 & 47.2 & 26.7 & 10 \\
\hline & ICMA 97111 x CZI 2010/11 & 45 & 216.9 & 18.6 & 2.6 & 1.8 & 8.8 & 46.2 & 22.1 & 12 \\
\hline \multirow[t]{3}{*}{ HT-3 } & ICMA 05444 x CZI 2003/1 & 45 & 216.2 & 20.2 & 2.3 & 2.2 & 8.6 & 74.0 & 32.6 & 4 \\
\hline & ICMA 00777 x CZI 2007/9 & 43 & 203.6 & 19.9 & 2.7 & 1.9 & 8.7 & 39.6 & 23.4 & 11 \\
\hline & ICMA 00777 x CZI 2003/8 & 45 & 231.1 & 20.8 & 2.5 & 2.2 & 6.9 & 43.1 & 20.7 & 14 \\
\hline \multirow[t]{2}{*}{ HT-4 } & ICMA 08111 x CZI 2003/1 & 45 & 231.6 & 22.8 & 2.7 & 1.7 & 10.2 & 57.6 & 30.7 & 6 \\
\hline & ICMA 09111 x CZI 99/8 & 44 & 198.5 & 24.1 & 2.7 & 2.2 & 7.6 & 36.5 & 20.8 & 13 \\
\hline
\end{tabular}

HT: Hybrid Trial 
Table.3 Variability observed in the test hybrid in arid conditions

\begin{tabular}{|l|c|c|c|c|}
\hline \multicolumn{1}{|c|}{ Characters } & Mean & Min & Max & $\begin{array}{c}\text { Variation (\%) } \\
\text { based on } \\
\text { overall mean }\end{array}$ \\
\hline Days to 50\% flowering & 47.53 & 41.30 & 54.3 & 5.49 \\
\hline Plant height $(\mathbf{c m})$ & 220.96 & 130.10 & 265.3 & 8.60 \\
\hline Ear Length $(\mathbf{c m})$ & 21.68 & 17.50 & 45.00 & 11.86 \\
\hline Ear Girth $(\mathbf{c m})$ & 2.57 & 1.90 & 3.10 & 9.40 \\
\hline Effective tillers (nos.) & 2.27 & 1.10 & 4.10 & 24.91 \\
\hline Test weight $(\mathbf{g})$ & 8.23 & 5.90 & 11.30 & 13.35 \\
\hline Fodder yield $\left(\mathbf{q ~ h a}^{-1}\right.$ ) & 60.69 & 26.70 & 112.5 & 24.26 \\
\left.\hline${\text { Grain Yield }\left(\mathbf{q ~ h a ~}^{-1}\right)}^{-1}\right)$ & 27.63 & 10.20 & 42.5 & 20.68 \\
\hline
\end{tabular}

Table.4 Correlations between different yield and yield attributes

\begin{tabular}{|c|c|c|c|c|c|c|c|c|}
\hline Characters & $\begin{array}{c}\text { Day to } \\
50 \% \\
\text { floweri } \\
\text { ng }\end{array}$ & $\begin{array}{c}\text { Plant } \\
\text { height } \\
\text { (cm) }\end{array}$ & $\begin{array}{c}\text { Ear } \\
\text { head } \\
\text { length } \\
(\mathrm{cm})\end{array}$ & $\begin{array}{l}\text { Ear } \\
\text { head } \\
\text { girth } \\
(\mathrm{cm})\end{array}$ & $\begin{array}{c}\text { Effective } \\
\text { tillers } \\
\text { (nos.) }\end{array}$ & $\begin{array}{l}\text { Test } \\
\text { weight } \\
\text { (g) }\end{array}$ & $\begin{array}{c}\text { Fodder } \\
\text { yield } \\
\left(\mathbf{q} \text { ha }^{-1}\right)\end{array}$ & $\begin{array}{c}\text { Grain } \\
\text { yield } \\
(\mathbf{q} \text { ha } \\
\left.{ }_{1}\right)\end{array}$ \\
\hline Days to $50 \%$ flowering & 1.00 & $0.36 * *$ & $0.19 * *$ & $0.42^{* * *}$ & -0.06 & $-0.16^{*}$ & $0.41 * *$ & -0.08 \\
\hline Plant height (cm) & & 1.00 & $0.33^{* *}$ & $0.15^{*}$ & -0.06 & -0.11 & $0.46^{* *}$ & $0.20^{* *}$ \\
\hline Ear length (cm) & & & 1.00 & 0.10 & -0.09 & -0.06 & 0.03 & $0.15^{*}$ \\
\hline Ear girth $(\mathbf{c m})$ & & & & 1.00 & $-0.24 * *$ & $0.22 * *$ & $0.25 * *$ & $0.15^{*}$ \\
\hline Effective tillers (nos.) & & & & & 1.00 & $-0.15^{*}$ & -0.03 & 0.07 \\
\hline Test weight (g) & & & & & & 1.00 & -0.06 & -0.05 \\
\hline Fodder yield $\left(q\right.$ ha $\left.^{-1}\right)$ & & & & & & & 1.00 & $0.60^{* *}$ \\
\hline Grain yield $\left(\mathrm{q} \mathrm{ha}^{-1}\right)$ & & & & & & & & 1.00 \\
\hline
\end{tabular}

In the set of hybrids evaluated, hybrid ICMA 93333 x CZI 2003/1, ICMA 97111 x CZI 2003/1, ICMA 04999 x CZI 2010/11, ICMA 05444 x CZI 2003/1 and ICMA 93333 x CZI 2007/9 has high potential they are early and high yielder. The said hybrids need to be evaluated at multi-location in arid regions for identification of potential hybrids for commercial cultivation in the western arid parts of India.

\section{Acknowledgement}

Authors gratefully acknowledge ICRISAT, Patancheru, for sharing of male sterile lines for development of test hybrids and Director CAZRI for providing needful facility and support.

\section{References}

1. Jalaja, N., Maheshwari, P., Naidu, K.R., and Kavi Kishor, P.B. 2016. In vitro regeneration and optimization of conditions for transformation methods in Pearl millet, Pennisetum glaucum (L.). International Journal of Clinical \& Biological Sciences. 1: 34-52.

2. Singh, N., Singh, S.P., Kumar, M., Kanhiya, K. and Kumar, A. 2018. Nutri 
Cereal Pearlmillet: Way Forward. International Journal of Current Microbiology and Applied Sciences. 7 (6): $578-581$.

3. Are, A. K., Srivastava, R. K., Mahalingam, G., Gorthy, S., Gaddameddi, A., Kunapareddy, A., Kotla, A. and Jaganathan, J. 2018. Application of plant breeding and genomics for improved sorghum and pearl millet grain nutritional quality: In Sorghum and Millets, $\mathrm{II}^{\text {nd }}$ Ed. Elsevier International. Pp 51-68.

4. Solanki, R. K., Mahla, H. R., Kakani, R. K., Choudhary, K. B. and Sharma, R. 2018. Stress tolerant crop varieties of major arid zone crops to promote resilience to climatic stresses. Indian Farming. 68 (9): 41-45.

5. Yadav, O. P., Singh, D. V., Vadez, V., Gupta, S. K., Rajpurohit, B. S. and Shekhawat, P. S. 2017. Improving pearl millet for drought tolerance - Retrospect and prospects. Indian Journal of Genetics and Plant Breeding. 77(4): 464-474.

6. Manga, V. K., Aravind, J. K. and Bhatt, R. K. 2015. Adaptation and selection of crop varieties for hot arid climate of Rajasthan. Indian Journal of Plant Sciences. 4(4): 1-9.

\section{How to cite this article:}

Solanki, R.K., R.K. Kakani, A.K. Jukanti, S.K. Singh and Bhatt, R.K. 2019. Performance of Pearl Millet Hybrids for Earliness and Grain Yield in Indian Hot Arid Region. Int.J.Curr.Microbiol.App.Sci. 8(03): 1956-1962. doi: https://doi.org/10.20546/ijcmas.2019.803.232 